\title{
地域保険薬局における薬学的臨床研究を基盤としたファーマシューティカルケアの実践
}

\author{
佐 藤 弘希, ${ }^{*, a, b}$ 丸山 徹 ${ }^{b}$
}

\section{Practice of Pharmaceutical Care Based on a Clinical Pharmaceutical Research in a Community Pharmacy}

\author{
Hiroki SATO ${ }^{*, a, b}$ and Toru MARUYAMA ${ }^{b}$ \\ aPharma Daiwa Yuge Pharmacy, 646-136 Yuge, Tatutamachi, Kumamoto City 862-8002, Japan, and \\ ${ }^{b}$ Department of Biopharmaceutics, Graduate School of Pharmaceutical Sciences, Kumamoto \\ University, 5-1 Oe-honmachi, Kumamoto City 862-0973, Japan
}

(Received July 2, 2007)

\begin{abstract}
A clinical research is not only an important issue for hospital pharmacist but also for community pharmacist because it is necessary to practice high quality pharmaceutical care. It goes without saying that drug and patient's informations are of great importance to investigate the clinical research in community pharmacist. However, the accessibility of latter information is limited to prescription, medication note, medication and care records, interview to the patients for community pharmacist, so far. Therefore, likewise pharmaceutical care, the abilities that find and solve the problems is very important for the clinical research by community pharmacist. In addition, it should consider that it cooperates with the facilities such as the hospital and faculty of university. This paper give a summary account of the usefulness of clinical research on the practice of pharmaceutical care for community pharmacy using our three examples such as, 1) Evaluation of usefulness of population pharmacokinetics analysis results to community pharmacy -effect of smoking and gender difference on olanzapine dosages, 2) Investigation of binding of drugs with natural polymer supplements, 3) Health promotion by primary-care pharmacist -Usefulness of educational activitys for importance of folic acid intake in pregnancy-aged women, which have been worked together with hospital pharmacist, faculty of university, and community resident, respectively.
\end{abstract}

Key words_ community pharmacist; pharmaceutical care; clinical research

\section{1.はじめに}

薬剤師にとっての臨床研究とは, 患者に対して最 適な医療を提供するために必要な活動の 1 つであ る．当然のことながら，これは“街の科学者”であ る地域薬局薬剤師にとっても重要な課題であること は言うまでもない。ところで，薬剤師業務の目標は 質の高いファーマシューティカルケアを実践するこ とであるが，そのためには，科学的根拠に基づいた 情報を活用することが必要不可欠である。しかしな がら，医療現場では，かならずしも必要なときに必 要なだけの情報が入手できないことも多い。そのよ うなケースでは，場合によっては薬剤師自らが臨床

aファーマダイワ弓削薬局 (†862-8002 熊本市龍田町弓 削 646-136), $b$ 熊本大学大学院医学薬学研究部 (T8620973 熊本市大江本町 5-1)

*e-mail: uge-drug@se.kcn-tv.ne.jp

本総説は, 日本薬学会第 127 年会シンポジウム S47 で 発表したものを中心に記述したものである。
研究を試み，目的とする情報を作り出すことが要求 される，実際，われわれはこれまでに薬局利用者に 対する医薬品適正使用の推進及びより質の高い情報 提供を実践するために様々な臨床研究を行ってき

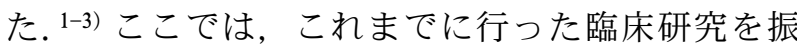
り返り, 地域保険薬局における臨床研究の在り方に ついて述べる.

\section{2. 薬局薬剤師が臨床研究を行う際の問題点} 地域保険薬局で臨床研究を行う場合, 物理的, 社 会的，制度的な種々の問題に直面する。例えば, ハード面では，小規模の施設が多いため研究設備が 整っていないこと, 他方, ソフト面では, 臨床研究 の基盤として久かすことのできない種々の情報が収 集しづらい状況におかれている。，一般に，臨床研究 で求められる情報は医薬品情報と患者情報の 2 つに 大別される，病院薬剤師の場合には，カルテや診療 情報などから患者背景や病歴，あるいは検査值など 
比較的詳細な患者情報が収集可能である。ところ が，地域薬局薬剤師では，処方箋，薬歴，お薬手帳 などからの限られた情報しか得ることができず，正 確な病歴や検査值といつた臨床研究に必要な患者情 報を収集し難く，臨床研究を遂行していく上でのボ トルネックになっている。われわれは，上述した問 題に対する解決方法の 1 つとして，他の地域薬局や 院内薬剤部，大学（薬学部）あるいは地域住民と積 極的に連携して成果を挙げてきた。

\section{3. 薬局薬剤師臨床研究を行う際に要求される能} 力

上述したように保険薬局において臨床研究を行う 目的は，質の高いファーマシューティカルケアを実 践し患者の QOL を向上させることである．そのた めには，現状の薬局業務やサービスにおける問題点 を見逃さない観察力に加えて，その本質を的確に見 抜く洞察力が必要となってくる。また，このように して抽出した問題を解決するための方法立案力やそ れを実行する行動力といつた問題解決能力も要求さ れる，残念ながら，これらの能力は短期間で身に付 くものではないため, 大学の教育課程や日々の薬局 業務の中で繰り返し訓練していく過程で培かわれて いくものと思われる.

\section{4. 保険薬局における薬学的臨床研究}

上述したように，自施設のみで臨床研究を進める ことが困難な場合，1）病院薬剤部や2）大学（薬 学部），あるいは3）市民と連携することで問題解 決に導くことができる（Fig. 1)。ここでは，それ ぞれの事例について紹介し，地域薬局薬剤師による

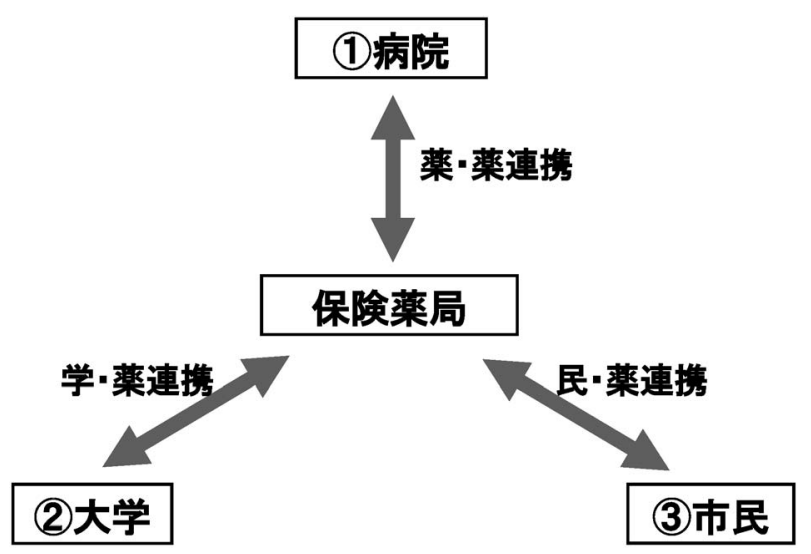

Fig. 1. Promotion of Clinical Research in Community Pharmacy by Cooperation with Other Facilities such as Hospital Pharmacy, University, Community Resident
臨床研究の進め方やその在り方について言及したい

\section{4-1. 病院薬剤部との薬・薬連携}

4-1-1. 事例(1)：ポピュレーションファーマコキ ネティクス解析データの有用性評価一オランザピン の投与量に及ぼす性差と喫煙の影響一＼cjkstart近年，統 合失調症の薬物治療において非定型抗精神病薬の才 ランザピンが汎用されているが，その有効性には個 人差があることが知られている。事実，治験段階に おける日本人のポピュレーションファーマコキネテ イクス（PPK）解析の結果から，クリアランスを 変化させる要因として喫煙と性差の影響が示唆され ている.4)特に，喫煙については，統合失調症患者 における喫煙率が一般人口に比べ有意に高いという 報告があるほか, 5,6) われわれが実施したオランザピ ン服用患者を対象とした調査においても同様な結果 が得られたことから（Table 1)，相互作用に対する 十分な注意が必要である.

ところが，実際に，これらの因子が実地医家の処 方に対してどの程度影響を及ぼしているのかを具体 的に検証した市販後の調查結果は見当たらない。ま た，PPK は薬物血中濃度モニタリング（TDM）を 行うための解析方法として繁用されているが，同時 に解析結果は投与量に関連するクリアランスへの寄 与因子や副作用のリスク因子を把握することができ る。そのため，処方監査や副作用モニタリング，あ るいは情報提供など薬剤師業務において有用な情報 を提供してくれる．特に，地域保険薬局のように， 血中濃度や検査值など患者情報の入手が限られてい る場合には薬剂師業務において非常に有用な情報に なり得ると思われる。この点を明らかにするため に，臨床現場で得られた結果を PPK 解析の結果と 比較することは地域保険薬局における PPK の有用 性を検証する上でも意義深いものと思われる。

そこで，当薬局においてオランザピンが処方され

Table 1. Smoking Prevalence of Patients who Treats with Olanzapine as Compare to General Populations in Japanese 喫煙率 $(\%)$

\begin{tabular}{ccccc}
\hline \hline & & 患者 & 日本人 (成人) ${ }^{a)}$ & 日本人 $\left(30-49\right.$ 歳) ${ }^{b)}$ \\
\hline 男 & 性 & 68.8 & 46.8 & $54.4-56.8$ \\
女 性 & 27.7 & 11.3 & $10.7-18.1$ \\
平均値 & 48.3 & 29.1 & $32.6-37.5$
\end{tabular}

$a ）$ 厚労省国民栄養調査（平成 15 年)，b）厚労省国民栄養調査（平成 15 年) のうち 30-49 歳の平均喫煙率。 
た外来患者 95 名を対象に，オランザピンの投与量 に対する性別及び喫煙の影響について調查を行つ た．その際，調査前後 1 力月間に処方変更があった 場合や，オランザピンのクリアランスに影響を与え る薬剂が処方されている患者は調査対象外とした. また，退院時，外来通院となつた患者については院 内薬剂部と連携し患者情報を入手した。

処方調查を行った結果，オランザピンの投与量は 非喫煙者に比べ喫煙者の方が有意に高い值を示した (Fig. 2)。また，女性よりも男性の方が高用量を処 方されていることが判明した。ここで，男女間の体 重差を考慮し，体重補正を加えて同様な検討を行つ たところ，女性よりも男性の方で投与量が大きくな る傾向が認められた $(p=0.062)$ 。一方，インタビ ユーフォームに記載されているオランザピンの PPK 解析データでは，最もクリアランスの大きい グループである男性喫煙群 $(14.3 \mathrm{l} / \mathrm{h})$ と最も小さ い女性非喫煙群 $(11.01 / \mathrm{h})$ との差異は約 1.3 倍異 なっているが，これは本研究より明らかとなった体 重補正後の投与量の差異（約 1.3 倍）と一致してい た (Fig. 3).

今回の調査に際し，処方医は患者の状態をみなが らさじ加減を行って投与量を設定おり PPK 解析 データの内容については知らなかった。そのため, 今回の投与量の差異は性別や喫煙といつた因子が影 響して, 結果的に PPK 解析結果を反映したものと 推察される。つまり，オランザピンの PPK 解析結 果は実地医家の処方を十分に反映しており，保険薬 局におけるファーマシューティカルケアを実践する

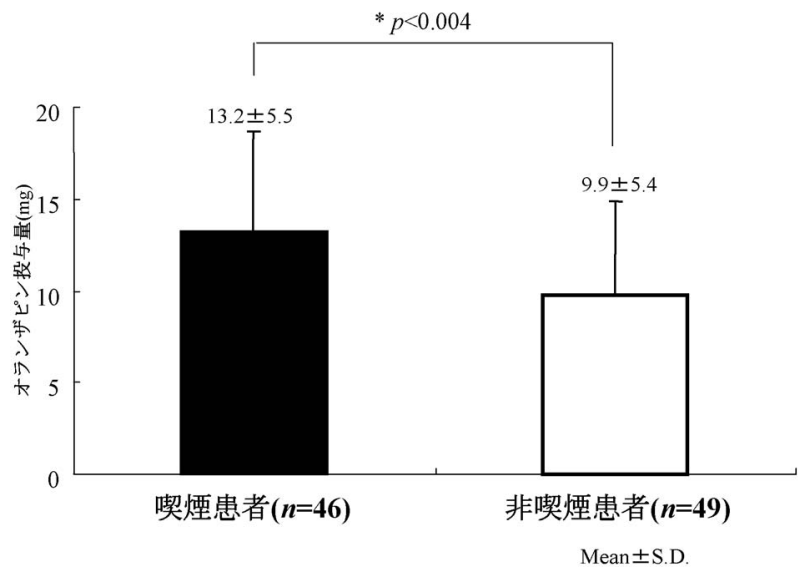

Fig. 2. Relationship between Olanzapine Daily Dosages and Smoking in Schizophrenia Patients
上での有用な情報である可能性が示唆された.

本研究のように地域保険薬局が院内薬剤部とうま く連携ができるようになると患者情報へのアクセス 制限という薬局薬剤師が抱える問題点は解決され る. 現在, 本研究の成果は, 当薬局においてオラン ザピン服用患者に対する処方監査や服薬指導の際に 活用している．また，処方医に対しても本研究内容 を紹介し，オランザピンの処方設計における問題点 を認識してもらうとともに外来患者の喫煙状況につ いて定期的に情報提供を行い，処方設計を支援して いる.

ただし，残念なことに，保険薬局薬剤師を対象と して，PPK 解析デー夕に関する調査を行ったとこ ろ，PPK に関する認知度はある程度あったものの, PPK 解析結果が添付文書に記載されていることや それを業務に活かしているケースはほとんど認めら れなかった（Fig. 4)。今後は本研究結果を参考に, 地域薬局薬剤師に PPK 解析結果を薬剂師業務に活 用するメリットを啓発していく必要があると考えて いる.

さらに残念なことに，添付文章の医薬品情報項に PPK 解析デー夕が記載されている割合は非常に少 ない，今後は製薬メーカーに対しても多くの薬剤で PPK データの添付文章あるいはインタビューフ オームへ記載してもらえるように啓発活動を行って いく必要があると考えている.

\section{4-2. 大学との学・薬連携}

4-2-1. 事例(2)：天然高分子サプリメントに対す る薬物の結合性に関する検討＼cjkstart近年の健康ブーム を反映してサプリメントの利用者が急増している.

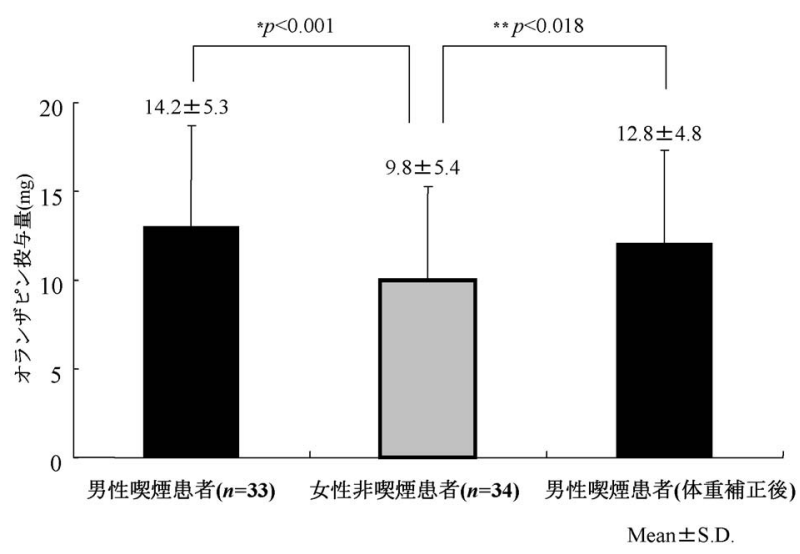

Fig. 3. Comparison of Olanzapine Daily Dosages between Male Smoking Group and Female Non-smoking Group 
Q1 :PPK の名称を四いたことがあるか?

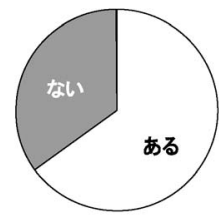

Q1 :PPK データが添付文章に記截されている ことを知っているか?
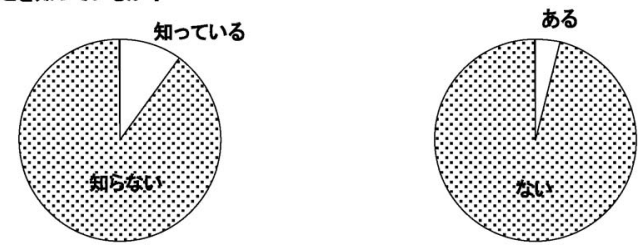

Fig. 4. Questionnaire Survey about PPK to Community Pharmacists $(n=31)$

中でも, 統合失調症, がんあるいは循環器疾患患者 の場合，治療薬とサプリメントを併用している場合 が多い。事実，われわれも店頭で処方薬とサプリメ ントの併用，いわゆる “飲み合わせ”に関する質問 を受ける機会が多い。つまり，これからの地域薬局 薬剤師にはサプリメントと医薬品との相互作用に対 する適正なマネージメント能力が求められる。 しか しながら現状では，サプリメントと医薬品との相互 作用に関する情報は不足しており，薬剤師が適切な アドバイスを行うには困難な状況である.

サプリメントの中でも，食物繊維，タンパク質， 糖類といった天然高分子は整腸，血糖降下，脂質低 下といつた多様な機能を有しているため，非常に人 気のある機能成分である，そのため，これらのサプ リメントを利用している人では医薬品を服用してい る割合が多く，必然的に両者の相互作用に関する質 問を受ける機会も多い。ところで，これら高分子素 材は疎水性や親水性あるいは電荷の有無といつた様 々な物理化学的な性質を有しており，医薬品と同時 に併用すると，消化管で両者が結合することによつ て医薬品の消化管からの吸収阻害を引き起こす可能 性が懸念される. ${ }^{7)}$

しかしながら，この問題に関する研究に着手した 当時は，高分子サプリメントと医薬品との相互作用 に関する系統だった研究はほとんどなされていなか つた．そこで，この問題の一端を明らかにするため に，繁用されている天然高分子サプリメントの市販 製品を用いて薬物との結合性に関する基礎的な検討 を行った。ここではサプリメントとして高分子を謳
つている市販品，低分子化アルギン酸ナトリウム， グアーガム分解物, キトサン, 小麦アルブミン, ビール酵母由来食物繊維，難消化性デキストリンの 6 種類を選択した。一方，モデル薬物としては，酸 性，塩基性薬物であるワルファリン，ケトプロフェ ン，クロルプロマジンを選択した。両者の結合性に ついては限外ろ過法により評価を行った.

その結果，Table 2 に示すように，特にキトサン において非常に高い結合性が観察された。キトサン はキチンを脱アセチル化することにより精製される が，この過程においてキトサン分子中に多くのアミ ノ基が遊離される．今回，キトサンが酸性薬物に対 して高い結合性を示したことから，結合過程には疎 水相互作用やファンデルワールスカに加え, キトサ ン分子中のアミノ基を介する静電的相互作用や水素 結合が重要な役割を果たしている可能性が示唆され た.

ところで，ワルファリンは生理活性が高く，細か い用量設定が必要な薬物であるため，このような結 合性の影響が特に問題となり易い。そこで，キトサ ンとワルファリンの組み合わせについてさらなる検 討を加えた. Figure 5 はキトサンとワルファリンの 結合性を製品間で比較したものである，予想に反 し，キトサンに対するワルファリンの結合性はほと んどないものから約 70\%程度と非常に高いものま であり，製品間で大きく異なっていることが判明し た。このことは，個々のキトサン製品に対する薬物 の結合性についての予測が非常に困難であることを 意味している.

一般にサプリメントは医薬品に比べ製造過程や品 質管理に関する規制が厳しくないため，製造メー カー毎に製法が異なる。 その結果，同じサプリメン トであっても，有効成分の含量や精製度，添加物の 種類，さらには不純物の混入度がメーカーにより異 なることがある。これらを考慮すると，今回キトサ ンの製品間で観察された結合性の差異は，キトサン の含量や脱アセチル化度の違い，あるいは脂肪酸工 ステルといつた配合物質の違いが影響している可能 性が推察される。

以上の結果より，キトサンをはじめとする高分子 サプリメントと薬物の併用は，結合による吸収阻害 が引き起こされる可能性が示唆された.

この調査後，他の薬局からこれまで INR のコン 
Table 2. Binding of Drug to the Natural Polymer Supplements by Ultrafiltration Technique

\begin{tabular}{|c|c|c|c|}
\hline & & 率 & $(\%)$ \\
\hline & ワルファリン & ケトプロフェン & クロルプロマジン \\
\hline 低分子化アルギン酸 Na & $7.34 \pm 0.90$ & $1.25 \pm 3.54$ & $2.56 \pm 2.11$ \\
\hline グァーガム分解物 & $1.85 \pm 5.90$ & $20.8 \pm 5.81$ & $3.62 \pm 5.11$ \\
\hline キトサン & $65.6 \pm 9.23$ & $83.1 \pm 0.75$ & $29.3 \pm 0.15$ \\
\hline 小麦アルブミン & $34.6 \pm 1.49$ & $11.6 \pm 0.40$ & $2.62 \pm 5.11$ \\
\hline ビール酵母由来食物繊維 & $1.98 \pm 5.97$ & $1.76 \pm 1.81$ & $3.82 \pm 2.11$ \\
\hline 難消化性デキストリン & $23.0 \pm 7.11$ & $2.55 \pm 1.58$ & $3.42 \pm 1.11$ \\
\hline
\end{tabular}

$n=5$, Mean \pm S.D

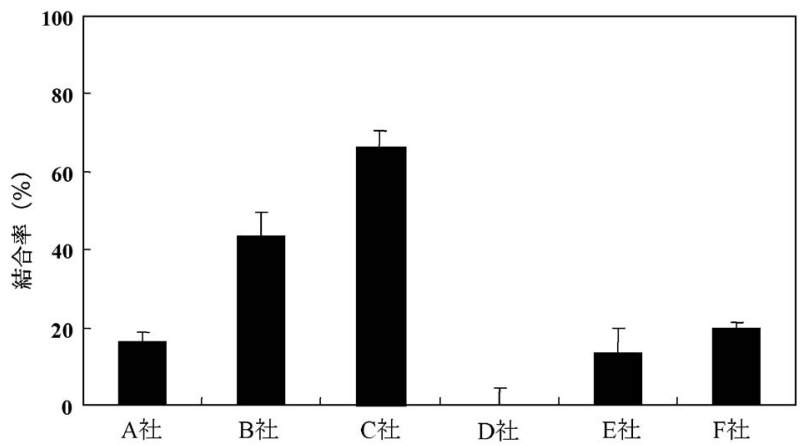

Fig. 5. Differences among Chitosan Products on Warfarin Binding

トロールが良好であつたワルファリン服用患者で， 急に INRが低下した症例について相談を受けた。 本ケースでは，INR の変動前後での処方薬の変更 や併用薬の有無，下痢や感染症等の体調変化，食生 活の変化もなかつた。 そこで，サプリメント摂取に 関するインタビューを行うよう提案したところ, INR の変動より 1 週間前からキトサン含有サプリ メントを摂取していたことが判明した。そのため, 担当薬剂師が本製品の摂取を直ちに控えるようアド バイスしたところ，INR は以前のレベルにコント ロールされるようになったケースを経験した。これ らの知見に基づき，現在では，ワルファリンだけで なく, 抗がん剂のように生理活性の高い薬物や免疫 抑制剂といつた TDM 対象薬物を服用している患者 に対しては，高分子サプリメントの摂取は避けるよ う指導している.

本研究のように日々の薬局業務で生じた問題が臨 床現場のみで解決することが難しい場合には，大学 などと連携して，一度基礎研究へ掘り下げるといつ た手段を選択することも真のファーマシューティカ ルケアを実践していく上で必要になってくるであろ う.

\section{4-3. 市民との民・薬連携}

4-3-1. 事例 (3)：葉酸摂取における認知度調査と 能動的情報提供 近年，葉酸が胎児の二分脊椎や 無脳症といつた神経管閉鎖障害の発症を低減するこ とが多くの疫学研究により明らかにされている. ${ }^{8,9)}$ そのため厚生労働省は妊娠可能な年齢の女性に対す る積極的な葉酸摂取を推奨している. 10) ところが, これまでいくつかの機関により実施された葉酸に関 する調査結果では，国民の妊婦に対する葉酸の有用 性に関する知識は乏しく，妊娠可能な女性が積極的 に葉酸を摂取しているケースは少ないようである. 事実，厚生労働省の葉酸摂取推奨後においても神経 管閉鎖障害の発症リスクは減少していない。

そこでわれわれは，地域住民に対するプライマリ ヘルスケア提供を目的として，10-20 代女性を対象 に葉酸に関する認知度調査を行うとともに適切な葉 酸摂取に関する能動的情報提供を行つた。その内容 としては，葉酸の有効性及び厚生労働省が推奨して いる適切な摂取量や方法を対象とした。 その後，再 度アンケートを実施して能動的情報提供前後におけ る市民の理解度変化を調査した。その結果，回答者 の大部分が葉酸に関する知識を持ち合わせていない ことが判明した（Fig.6）。しかしながら，薬剤師 が葉酸に関する能動的情報提供を実施することで, いずれの項目においても理解度の有意な改善が認め られるとともに，妊娠時に葉酸不足にならないよう 注意し, 場合によってはサプリメントの摂取を考慮 するとした意識の改善も見受けられた。 また今回， 作成した情報提供書は全般的に好評であり，今後も このような薬剤師オリジナルの情報提供を希望する 意見が多く寄せられた。したがって，地域薬局薬剂 師による健康情報の啓発活動は，地域住民のヘルス プロモーションを推進していく上での有用な手法で 


\section{Q1.葉酸という名前を聞いたことがありますか？}

\section{情報提供前}
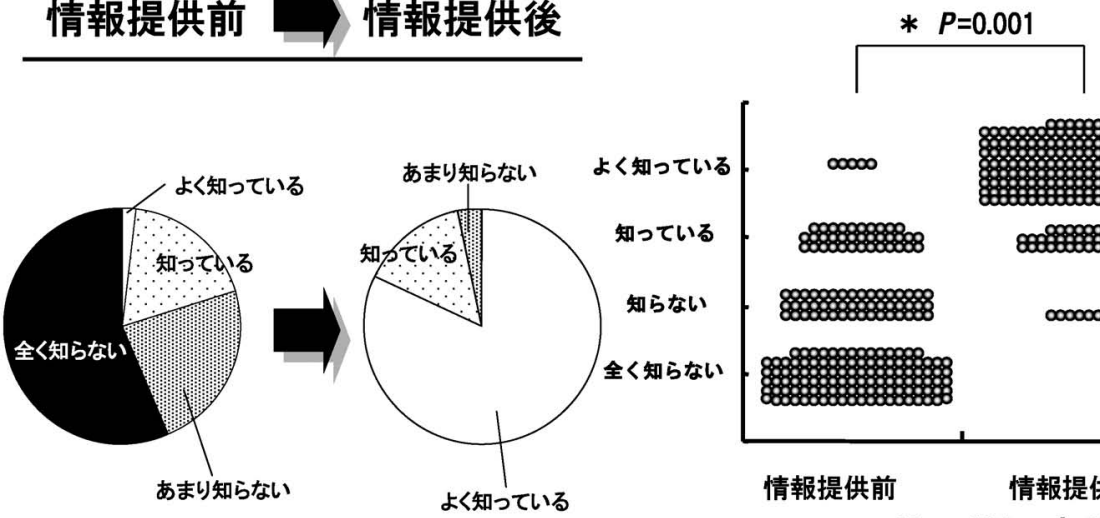

$\ldots$
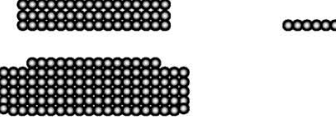

情報提供後

Mann-Whitney's U-test

\section{Q3.葉酸が赤ちゃんの先天性異常である二分㹃椎や無脳症} などの発症リスクを低減させることは知っていますか?

\section{情報提供前 $\Longrightarrow$ 情報提供後}

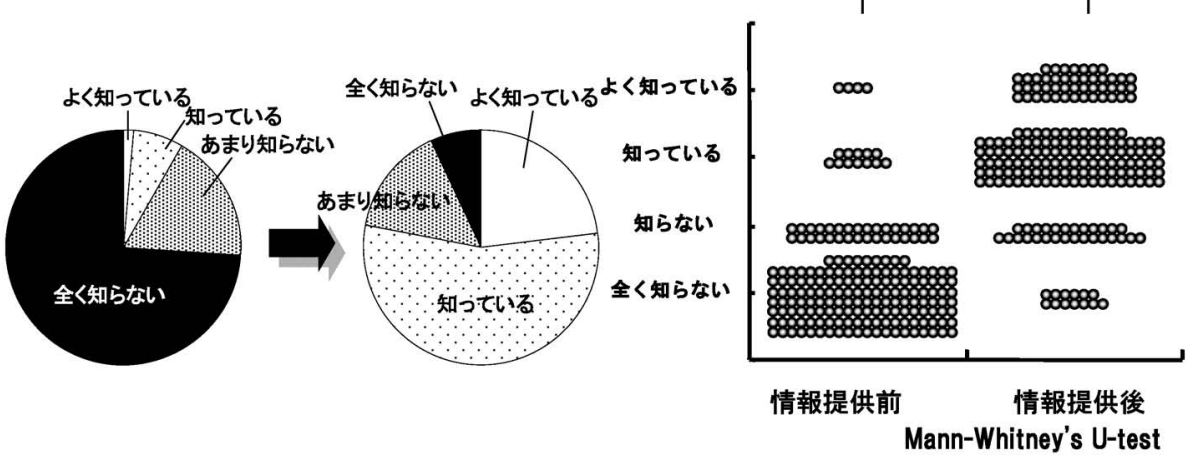

Fig. 6. Changes in the Understanding of Pregnancy-aged Women about Folic Acid Intake before and after Intervention Using Information Provision by Community Pharmacist

\section{ある可能性が示唆された.}

本研究はプライマリケアの一端を担う地域保険薬 局薬剤師が地域住民と連携し，ヘルスプロモーショ ンに積極的に介入する有用性をアンケート調査によ り評価した事例である。アンケート調査は，他の臨 床研究手法に比べて，低コストであり，特別な設備 も必要としないため，地域保険薬局のような比較的 研究環境が整つてない施設でも手軽に行える利点を 有している. ${ }^{11)}$ 現在，われわれも本研究を応用し て，他薬局と共同でヘルスケアに関する啓発活動を 鋭意実施している．このように地域に根ざす保険薬 局はプライマリケアの前線基地として機能すべきで あろう。

\section{5. おわりに}

地域薬局薬剤師は街の科学者あるいは地域医療に おけるケアチームの一員として地域住民のヘルスケ アにおける問題点を抽出し，それを解決するために 積極的に臨床研究を行う必要がある。ささら臨床研 究を基盤とした質の高いファーマシューティカルケ アやプライマリヘルスケアを実践することにより， 患者の QOL 向上や地域住民の健康維持に努めてい くことがこれからの地域薬局薬剤師に求められてく るであろう。

\section{REFERENCES}

1) Toru M., Kenji Y., Shinichi H., Arahira M., Hiroki S., Yoshida S., Yoshiro O., Maeda A., 
Keishi Y., Hiroshi M., Kenji K., Jpn. J. Pharm. Health Care Sci., 30, 608-613 (2004) .

2) Hiroki S., Toru M., Arahira M., Yoshida S., Maeda A., Kenji K., Yoshiro O., Keiishi Y., Jpn. J. Pharm. Health Care Sci., 31, 744-748 (2005).

3) Hiroki S., Toru M., Youko O., Emiko M., Keiko K., Rinko I., Yoshiro O., Makoto A., Msaki O., Jpn. J. Pharm. Health Care Sci., 32, 940-945 (2006).

4) Zyprexa ${ }^{\circledR}$ tablets, Eli Lilly Japan Co., Ltd., Interview form.

5) Lohr J. B., Flynn K., Schizophr. Res., 8, 93102 (1992).
6) Ziedonis D., Williams J. M., Smelson D., Am. J.Med. Sci., 326, 223-230 (2003).

7) Yasuhumi S., J. Pract. Pharm., 55, 231-233 (2004) .

8) Laurence K. M., James N., Miller M. H., Tennant G. B., Campbell H., Br. Med. J. (Clin. Res. Ed.), 282, 1509-1511 (1981).

9) MRC Vitamin Study Research Group., Lancet, 338, 131-137 (1991).

10) Ministry of Health, Labour and Welfare Home page: 〈http://www1.mhlw.go.jp/houdou/ 1212/h1228-1_18.html $\rangle, 2006$

11) Toru M., Hiroki S., J. Jpn. Pharm. Assoc., 59, 459-463 (2007). 